\title{
Using Soil Surveys to Map Quaternary Parent Materials and Landforms across the Des Moines Lobe of lowa and Minnesota
}

\author{
Bradley A. Miller, C. Lee Burras, and William G. Crumpton
}

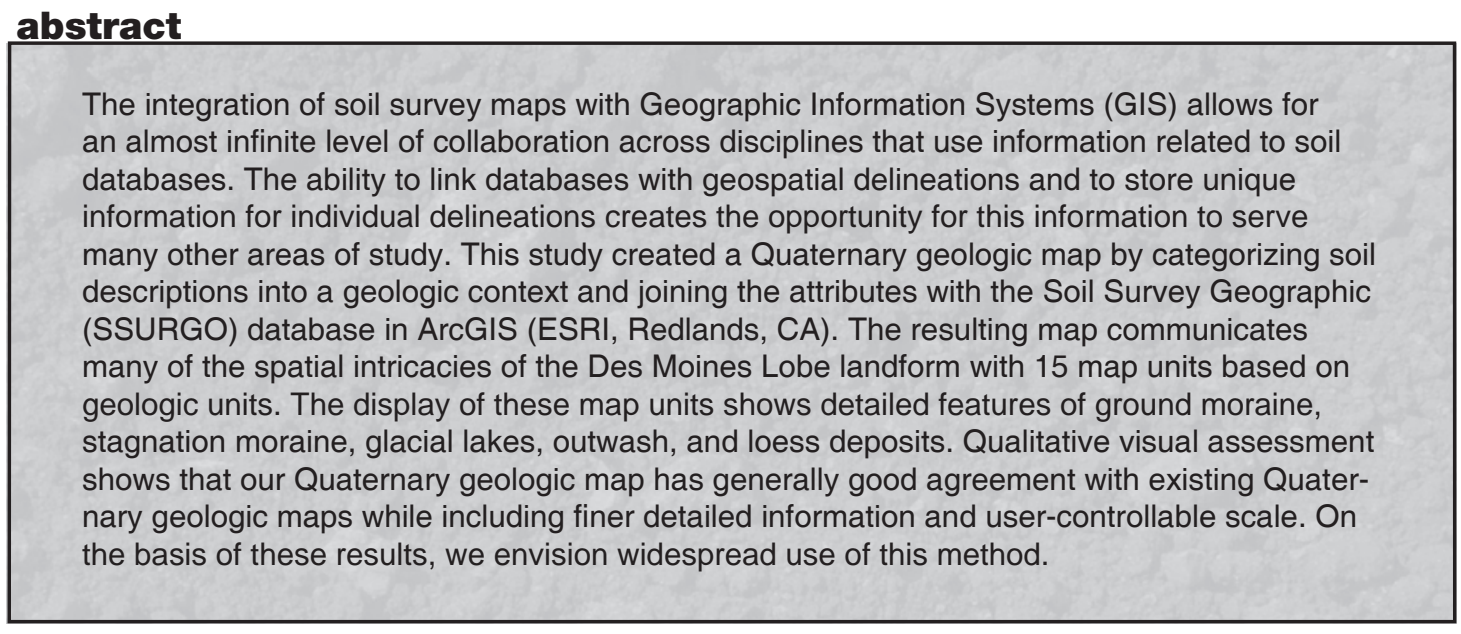

$S^{c}$ cience develops as disciplines share data, models, and concepts. A powerful tool for doing so across field sciences is a geographic information system (GIS) because it permits an almost infinite set of permutations in organization, manipulation, and distribution of diverse data. As a result, numerous hypotheses can be evaluated at minimal cost. Of course, evaluation reliability rests on the accuracy and quality of information used (Brodnig and Mayer-Schönberger, 2000). Hence, assurance of data quality is a critical parameter when using GIS. Anecdotally it appears two U.S. map databases consistently meet or exceed the needs of scientists. These are U.S. Geological Survey topographic maps and the U.S. National Cooperative Soil Survey (NCSS) soil survey maps. This report focuses on the latter.

Scientists publishing in journals of the Soil Science Society of America, Crop Science Society of America, and the American Society of Agronomy are examples of major users of NCSS data layers. Authors commonly meet journal requirements about soil series by using published NCSS data, especially the online soil survey (Soil Survey Staff, 2007a, 2007b). Those authors trust these data because the data collection is conducted in a rigorous, scientifically valid, systematic manner that includes national reviews and verification. In many cases, they consider it so scientifically familiar they do not cite where they obtained it.

Archeologists and anthropologists likewise routinely use soil survey as documentation of background data as well as data layers in predict-

B.A. Miller, Environmental Programs, lowa State University, 1126 Agronomy Hall, Ames, IA 50011 (miller@iastate.edu); C.L. Burras, Dep. of Agronomy, lowa State University; W.G. Crumpton, Dep. of Ecology, Evolution, and Organismal Biology, lowa State University. Published in Soil Surv. Horiz. 49:91-95 (2008). ing spatial and temporal interpretations about artifact probability (e.g., see Holliday, 2005). Geologists, ecologists, engineers, and planners interested in carbon storage, geochemistry, biogeography, and environmental risks, for example, do the same (e.g., see Manies et al., 2001, Muhs and Bettis, 2000, Norris et al., 2006, Simpkins et al., 2002). Just as with soil scientists and agronomists, NCSS data are sometimes considered so routine that it is documented as part of the methods but not cited in the bibliography (e.g., Simpkins et al., 2002).

The preceding paragraphs illustrate the ubiquitous nature of NCSS data across field sciences. It also shows most authors do not critically evaluate this data-a risk that will only grow as NCSS data becomes more and more buried within models and newer GIS packages. To evaluate that risk we decided to conduct this study. Our objectives were twofold. First, we sought to create the best possible Quaternary geology map of the Des Moines Lobe (Fig. 1) solely using readily available NCSS data. Second, we sought to test whether that map is comparable to Quaternary geology maps previously published by geologists.

We selected the Des Moines Lobe for this study because NCSS mapping across it heavily relies on the Quaternary landscape model developed by Ruhe (1969). In other words, we hypothesized that NCSS data and Quaternary maps are nearly one and the same on the Des Moines Lobe. Hence, one of the best tests for the utility of the NCSS data would be this comparison. We hypothesized that the resulting Quaternary map would be an improvement over existing surficial geologic maps because the NCSS puts considerably more resources into county soil surveys than found in most classical geologic maps (P.L. Moore, personal communication, 2006). 


\section{Methods}

\section{Creation of the NCSS-based} Quaternary Geologic Map

Digital county soil maps were obtained from the USDA-NRCS Soil Survey Geographic (SSURGO) Database (Soil Survey Staff, 2007a). We constructed a database that categorized each soil series that appeared in the selected counties for surface geologic attributes. The database key was based on terms found in the online Official Series Descriptions (Soil Survey Staff, 2007b). Since soil surveys, official series descriptions, and geological nomenclature continue to evolve, some interpretation was necessary in labeling soil map units in geologic unit terms. We then linked our database to the SSURGO shapefile in ESRI's ArcGIS 9.2 software.

Viewing this map at a regional scale made it necessary to group information that was available in the soil survey. The soils were displayed by grouping categorized soil into 15 geologic units. More detailed information, such as the type of rock for outcrops, is included with the soil survey description and maintained in the category codes created for this study. Some soil descriptions included buried parent materials, but for this study, the map was simplified by only displaying the surface parent material.

\section{Comparison with Existing Maps}

Quaternary geologic maps that were available in a GIS format were used to compare our Quaternary geologic map for level of agreement and detail. A digital version of H.C. Hobbs and J.E. Goebel's 1:500,000 scale paper map "Geologic Map of Minnesota: Quaternary Geology" was available from the Land Management Information Center, Minnesota Planning, and Minnesota Geological Survey (2005). In lowa, a map of recognized moraines of the Des Moines Lobe from the lowa Geological Survey, Department of Natural Resources (1995) was the only available Quaternary geologic map available in GIS format. The lowa DNR produced the map by digitizing Mylar maps produced by Timothy J. Kemmis formerly of the lowa Geological Survey. We overlaid the line delineations of the Minnesota Quaternary geologic map and the Des Moines Lobe moraines map on top of our Quaternary geologic map to check for agreement between published maps and our map. A detailed comparison of our map with the Minnesota Quaternary geologic map was made, as the latter map has the most detail available in a GIS format.

\section{Results}

The soil categorization produced a detailed map of the region's Quaternary geology (Fig. 2). Diverse geologic units associated with glacial lakes, outwash, till plains, and loess are displayed clearly. Holocene deposits of alluvium are distinguished in stream valleys. Rock outcrops are also identified, although they are not common in this landscape. Mapping each of these surface geologic features is useful for research and education. Figure 3 illustrates the level of detail present in our Quaternary geologic map. The shape of individual features and the intertwined nature of several landforms are illustrated by our map.

The published GIS geologic maps for both states show overall agreement with our map (Fig. 4). The boundaries between major geo- logic units coincide very well. The level of agreement is illustrated by the matching areas in north central Minnesota where there are pockets of Des Moines Lobe till, Wadena Lobe till, and outwash. There are some discrepancies between the Minnesota geologic map and our Quaternary geologic map. One example is where our Quaternary geologic map shows a significant region of Wisconsinan Loess and loamy sediments in the area of $44^{\circ} \mathrm{N}$ and $95.5^{\circ} \mathrm{W}$.

The other discrepancies generally coincide with disagreements between survey areas in our Quaternary geologic map. The glacial lake in the area of $45^{\circ} \mathrm{N}$ and $95.5^{\circ} \mathrm{W}$ has a common eastern border with a county line. The same county line to the north shows deposits from the Wadena Lobe mapped as ending abruptly west of the line.

Since our Quaternary geologic map is based on soil survey delineations mapped at the 1:15,840 scale (Soil Survey Division Staff, 1993) and the smallest scale Quaternary geologic map found published for this area was 1:500,000, our Quaternary geologic map has the ability to show smaller details. The difference in detail is visualized by our Quaternary geologic map's delineations of smaller areas such as lakes, rock outcrops, local eolian deposits, and alluvial deposits (Fig. 5). The inclusion of an additional map unit for concave areas on Des Moines Lobe Till displays the shape of individual landforms. This creates the opportunity to interpret the landforms as products from various glacial processes.

A major benefit from representing geologic units in fine detail with color-coded delineations is the ability to show the intermixed relationship of formations. For example, areas of outwash intertwined with other features are displayed in finer detail. The level of detail available in our Quaternary geologic map corresponds with and is complemented by a hillshade derived from a digital elevation model (Fig. 6). Delineated geologic units are small enough to correspond with landform shapes displayed by the United States Geological Survey's 30-m resolution elevation hillshade. 

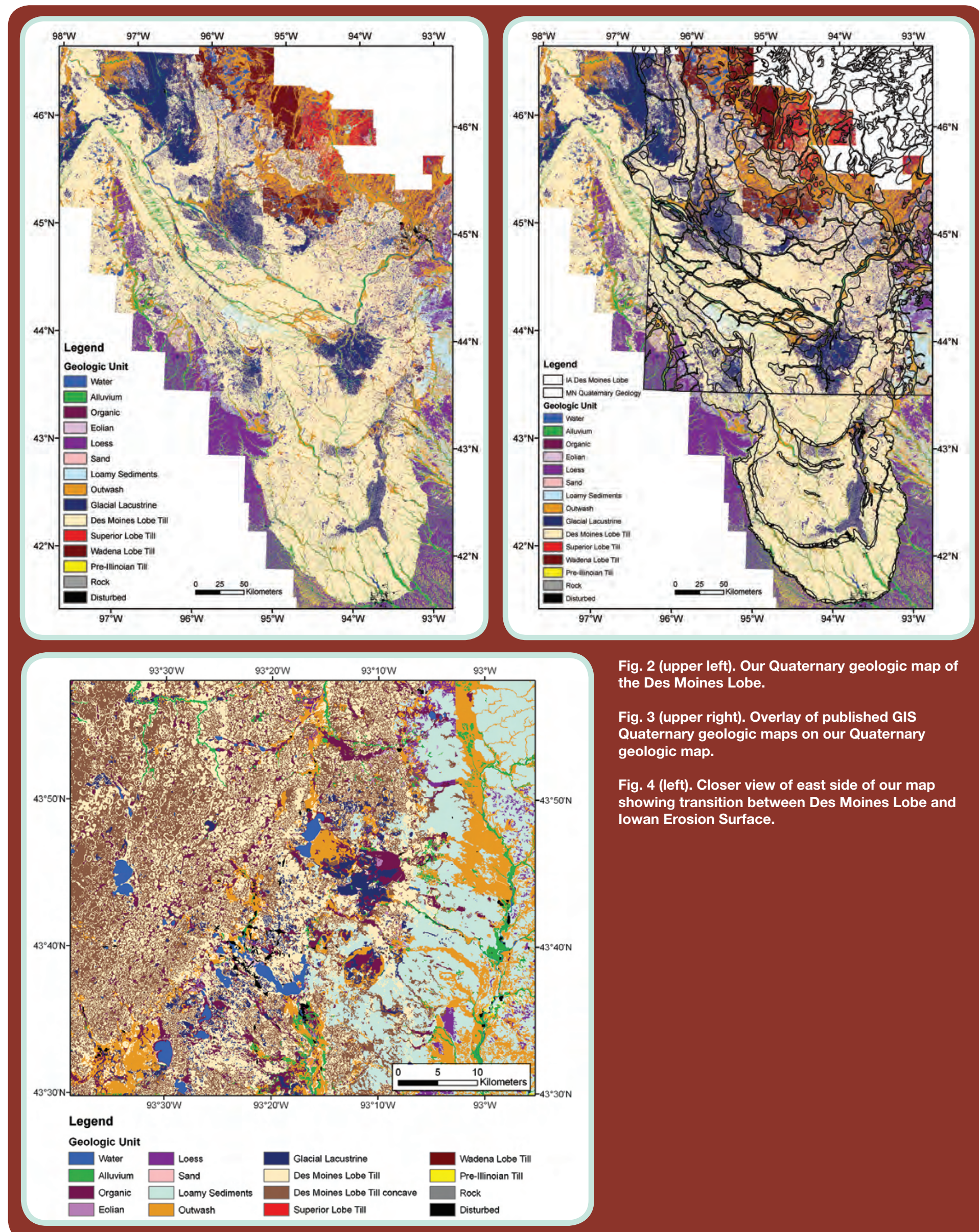

Fig. 2 (upper left). Our Quaternary geologic map of the Des Moines Lobe.

Fig. 3 (upper right). Overlay of published GIS

Quaternary geologic maps on our Quaternary geologic map.

Fig. 4 (left). Closer view of east side of our map showing transition between Des Moines Lobe and lowan Erosion Surface. 


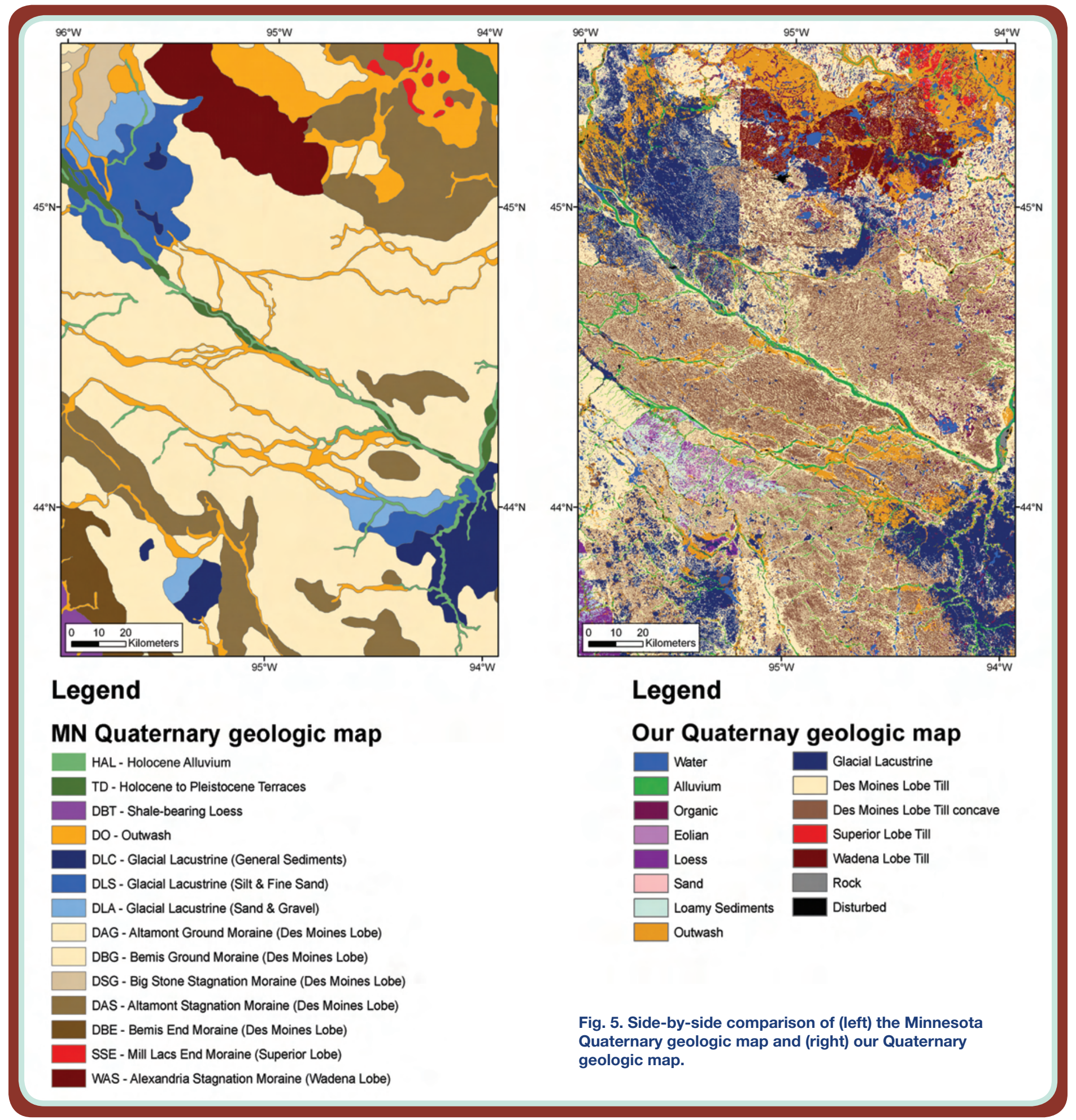

Regional maps generally delineate by spatial majority groups. Finescale maps with appropriate groupings in the legend can still be viewed at a regional scale and provide more information about the landscape. If a more condensed map is desired, the finer detailed map should be used as a basis for better precision and accuracy.

\section{Discussion}

There are instances where the Minnesota Quaternary geologic map and our Quaternary geologic map disagree about the extent of a geologic feature. For example, according to our Quaternary geologic map, the glacial lake in south-central Minnesota extends farther south than shown by the Minnesota Quaternary geologic map. It is difficult to judge from this investigation which is correct. Ground-truthing is the only way to verify which is correct. The soil survey has the benefit of extensive field observations to correlate similar materials. Although the soil surveyors did not have geologic mapping responsibilities when they created the soil map, their numerous field observations lend credibility to their delineations. 


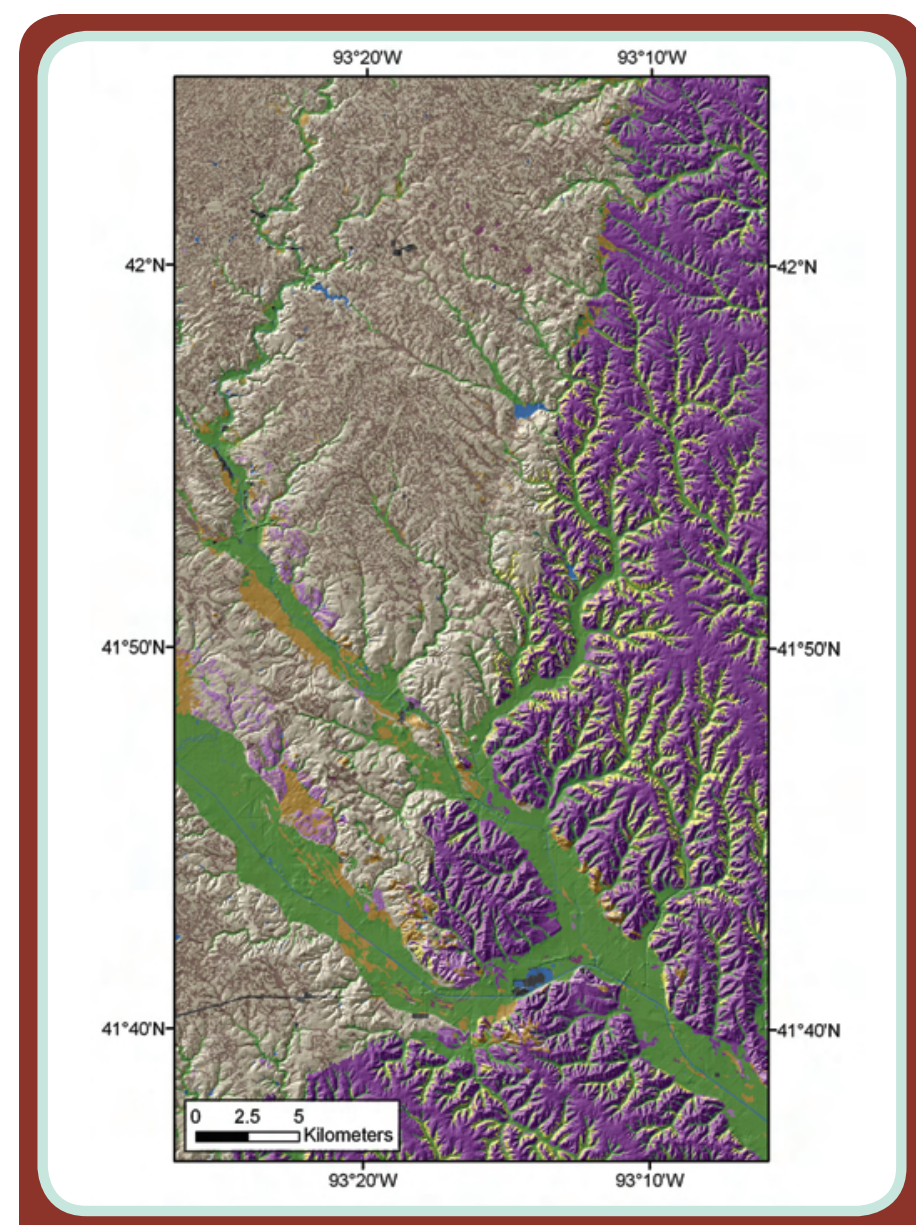

Fig. 6. Elevation hillshade overlaid with our Quaternary geologic map (see legend from our Quaternary geologic map in Fig. 5).

Compiling county soil maps together for regional assessments has strengths and weaknesses. Each county is surveyed at different times and often by different people. It is a strength for the map when there is agreement across survey areas from independent mapping. However, aggregating survey areas does show some impractical divisions in soil property mapping, such as the glacial lake below the Big Stone moraine in central Minnesota having a linear eastern boundary that coincides with the county line. This is unlikely to be the true shape of this lake. Recognition of these discrepancies should lead to further investigation and improved accuracy for future mapping.

Soil descriptions include more detail about the properties of map units than was included in the categories used to make our Quaternary geology map. For instance, the Soil Survey Manual (Soil Survey Division Staff, 1993) defines specific ranges of slopes for terms including undulating, rolling, and hilly. Any property that has been recorded within a standardized methodology like this could be interpreted and displayed in a context useful for the intended area of study.

While this manuscript was in progress, additional counties in the study area became available. Since these counties contained the same soils, the same key was used to add them to the map. Adding the additional areas only took a few minutes each, illustrating the time efficiency of this method. The reliance on the key is also a potential source of error. A misinterpretation of a soil or a data entry mistake would propagate through that soil's mapped extent.
It should be noted that SSURGO does include a linkable, parent material attribute. This attribute does not put the material in as much of a geologic context as the interpretation on our map has, but still provides much of the information needed for producing a Quaternary geologic map. The great advantage of GIS is that attributes to spatial data can be added at any time by correlating with an identification field in the SSURGO database. We believe a real opportunity exists in creating linkable databases that can be used consistently across political boundaries, disciplines, and regional terminologies.

\section{Conclusions}

Categorization of soil map units with respect to geologic unit successfully created a detailed Quaternary geologic map for the Des Moines Lobe, showing strong agreement with the existing Quaternary geologic maps while adding a user-controlled level of scale.

There are differences between existing Quaternary geologic maps and our Quaternary geologic. Increased dialog between disciplines and ground-truthing could help resolve these differences and perhaps answer questions that have remained for both groups. For example, the level of detail surveyed by soil scientists could help geologists decipher ambiguous or complicated areas of multiple glacial advances.

After the development of keys that relate soil survey terminology to information of geologic interest, the use of the soil survey will be a quick and easy reference for geologic inquiry. The same concept applies to any discipline affected by soil properties. Within the soil survey, soil series are expected to consistently describe a defined range of soil properties. Those definitions should be used to create a spatially linked database for the attributes of interest. In the future, other soil properties could be added and studied spatially at practically any scale.

\section{References}

Brodnig, G., and V. Mayer-Schönberger. 2000. Bridging the gap: The role of spatial information technologies in the integration of traditional environmental knowledge and Western science. Electron. J. Inform. Syst. Develop. Countries 1:1-15.

Holliday, V.T. 2005. Soils in archaeological research. Oxford Univ. Press, New York.

lowa Geological Survey, Department of Natural Resources, 1995. The Des Moines Lobe and its glacial advances in lowa. Available at http://www.igsb.uiowa.edu/ nrgislibx/ (verified 22 Dec. 2008).

Land Management Information Center, Minnesota Planning, and Minnesota Geological Survey. 2005. Geologic Map of Minnesota: Quaternary Geology, from MGS (Map S-1), 1982 (Digital Version).Available at http://www.Imic.state. $\mathrm{mn}$. us/chouse/metadata/quatgeo.html (verified 22 Dec. 2008).

Manies, K.L., J.W. Harden, L. Kramer, and W.J. Parton. 2001. Carbon dynamics within agricultural and native sites in the loess region of western lowa. Glob. Change Biol. 7:545-555.

Muhs, D.R., and E.A. Bettis, III. 2000. Geochemical variations in Peoria loess of western lowa indicate paleowinds of midcontinental North America during last Glaciation. Quat. Res. 53:49-61.

Norris, J.R., S.T. Jackson, and J.L. Betancourt. 2006. Classification tree and minimum-volume ellipsoid analyses of the distribution of ponderosa pine in the western USA. J. Biogeogr. 33:342-360.

Ruhe, R.V. 1969. Quaternary landscapes in lowa. lowa State Univ. Press, Ames.

Simpkins, W.W., M.R. Burkart, M.F. Helmke, T.N. Twedt, D.E. James, R.J. Jaquis, and K.J. Cole. 2002. Potential impact of earthen waste storage structures on water resources in lowa. J. Am. Water Res. Assoc. 38:759-771.

Soil Survey Division Staff. 1993. Soil survey manual. Agric. Handb. 18. USDA-SCS. U.S. Gov. Print. Office, Washington, DC.

Soil Survey Staff. 2007a. Soil Survey Geographic (SSURGO) Database. Available at http://soildatamart.nrcs.usda.gov (verified 22 Dec. 2008). USDA-NRCS.

Soil Survey Staff. 2007b. Official soil series descriptions (OSD). Available at http://soils. usda.gov/technical/classification/osd/ (verified 22 Dec. 2008). USDA-NRCS. 